\title{
PERAN PESANTREN ENTREPREUNER DALAM PENGEMBANGAN MASYARAKAT (STUDI KASUS PESANTREN ENTREPREUNER BEKASI)
}

\author{
Muhammad Shibgotulloh \\ (Alumni STEI SEBI) \\ \& \\ Efri Syamsul Bahri \\ (Dosen STEI SEBI)
}

\begin{abstract}
Pesantren Entrepreneur is an Islamic dormitory school that has dakwah activity as well as a business activity. Business activity becomes one of society development indicator. In a hadith, Rasul Saw said, 9 of 10 luck is from trading. Unfortunately, it is many people still think to get luck by becoming an employer. Run a business is a way to get a luck that people can do. Moreover, Indonesia is a country that has so much of natural resources. Nevertheless, up to now, many Indonesian are unable to take that great chance. Indonesia has a great potential. If Indonesian is able to take the chance then the poverty will easily to be removed. Moreover, Pesantren Entrepreneur has many programs of society empowerment, particularly in a small micro enterprise sector. Based on the statement above, it is so interesting to discuss about Society Empowerment and the steps in Pesantren Entrepreneur to Empower Society in Small Micro Enterprise sector.
\end{abstract}

Keywords: Pesantren Entrepreuner, aktivitas bisnis, Micro Entreprise, Emporwer Society

\section{PENDAHULUAN}

Pasca krisis moneter tahun 1998, Indonesia dihadapkan pada kondisi ekonomi yang tidak stabil. Bencana alam yang kerap terjadi melanda Indonesia menambah beban pemerintah dalam pembangunan. Disisi lain, masyarakat kecil mengalami kesulitan dalam berusaha dan menjalankan aktivitas disektor ekonomi. Hal ini bisa dilihat dari data Badan Pusat Statistik (2012) yang menunjukkan, jumlah penduduk miskin di Indonesia pada maret 2012 mencapai 29,13 juta orang (11,96\%), berkurang 0,89 juta orang $(0,53 \%)$ dibandingkan dengan penduduk miskin pada maret 2011 yang sebesar 30,02 juta orang (12,49\%) selama periode maret 2011 - maret 2012, penduduk miskin daerah perkotaan berkurang sekitar 399,5 ribu orang (dari 11,05 juta orang pada maret 2011 menjadi 10,65 juta orang pada maret 2012). Sementara didaerah pedesaan berkurang 487 ribu orang (dari 18,97 juta orang pada maret 2011 menjadi 
18,48 juta orang pada maret 2012). Peresentase penduduk miskin didaerah perkotaan pada maret 2011 sebesar 9,23\%, menurun menjadi $8,78 \%$ pada maret 2012. Begitu juga dengan penduduk miskin dipedesaan, yaitu dari $15,72 \%$ pada maret 2011 menurun menjadi $15,12 \%$ pada maret 2012 (BPS, 2012).

Kondisi kemiskinan Indonesia semakin menurun. Hal ini sebuah prestasi yang harus ditingkatkan. Dengan adanya LSM (Lembaga Swadaya Masyarakat) dan lembaga keuangan yang begitu banyak tentunya tidak dapat dipungkiri keberadaannya ikut berperan dalam pengentasan kemiskinan. Sederhananya keberadaan LSM (Lembaga Swadaya Masyarakat) dan lembaga keuangan dengan program pemberdayaan masyarakatnya pada bidang ekonomi telah berkontribusi membantu masyarakat miskin dalam meningkatkan perekonomiannya.

Pemberdayaan berasal dari kata "daya" yang mendapat awalan "ber" yang menjadi kata "berdaya" artinya memiliki atau mempunyai daya. Daya artinya kekuatan, berdaya artinya memiliki kekuatan. Pemberdayaan dalam bahasa Indonesia merupakan terjemahan dari empowerment dalam bahasa inggris.

Pemberdayaan merupakan proses peningkatan kemampuan seseorang atau kelompok baik dalam arti pengetahuan, keterampilan, maupun sikap agar dapat memahami dan mengontrol kekuatan social, ekonomi dan politik sehingga dapat memperbaiki kedudukan di masyarakat. Upaya pemberdayaan merujuk pada pengertian perluasan kebebasan memilih dan bertindak. Bagi masyarakat kalangan bawah, kebebasan ini sangat terbatas karena ketidak mampuan bersuara dan ketidakberdayaan dalam hubungannya dengan Negara dan pasar. Pemberdayaan masyarakat lapisan bawah dan terbelakang menurut upaya menghilangkan penyebab ketidakmampuan mereka meningkatkan kualitas hidupnya.

Proses pemberdayaan menekankan pada proses memberikan kemampuan kepada masyarakat agar menjadi berdaya, mendorong atau memotivasi individu agar mempunyai kemampuan atau keberdayaan untuk menentukan pilihan hidupnya. Orientasi usaha pemberdayaan ini bisa tertuju pada lapisan masyarakat bawah dengan memberikan motivasi atau dukungan yang tertuju pada individu sendiri dengan memberikan pendidikan dan keterampilan atau pelatihan untuk memulai dan mengelola suatu usaha. (Rukmana, 2013).

Pesantren entrepreuner adalah salah satu LSM (Lembaga Swadaya Masyarakat) yang dengan program pemberdayaannya mampu membina dan mendidik putra putri bangsa yang berkemauan keras menjadi 
wirausahawan yang unggul. Pembelajaran kewirausahaan yang diselenggarakan oleh pesantren entrepreuner lebih berkualitas dan kompeten dalam menghadapi tantangan global.

\section{LANDASAN TEORI}

\subsection{Pengertian Pesantren}

Secara etimologi pesantren berasal dari kata pesantrian yang berarti tempat santri. (zamakhsari Dhofier, tradisi pesantren: studi pandangan hidup kiai, (Jakarta: LP3ES, 1982) hlm 18) Sementara mastuhu mendefinisikan pesantren adalah lembaga pendidikan tradisional islam untuk memahami, menghayati, dan mengamalkan ajaran ajaran islam (tafaqquh fi al-din) dengan menekankan pentingnya moral agama islam sebagai pedoman hidup masyarakat sehari hari. (Mastuhu, 1994).

Adapun ciri ciri pesantren, mengutip pendapat Ziemek, ada tiga ciri: 1) kiai sebagai pendiri, pelaksana, dan guru. 2) pelajar (santri) secara pribadi diajari berdasarkan naskah naskah arab klasik tentang pengajaran, paham, dan akidah keislaman. 3) kiai dan santri tinggal bersama sama untuk masa yang lama, membentuk suatu komunitas seperti asrama, tempat mereka sering disebut pondok. (Ma'arif, 2008).

Menurut KH Imam Zarkasyi (1996) dalam buku pekan perkenalan pondok modern gontor, pesantren didefinisikan sebagai lembaga pendidikan islam dengan system asrama atau pondok, dimana kiai sebagai sentral figurnya, masjid sebagai pusat kegiatan yang menjiwainya, dan pengajaran agama islam dibawah bimbingan kiai yang diikuti santri sebagai kegiatannya.

Jadi, ada empat ciri utama pesantren. Pertama pondok harus berbentuk asrama. Kedua kiai sebagai sentral figure yang berfungsi sebagai guru, pendidik, atau pembimbing. Ketiga masjid sebagai pusat kegiatan. Dan yang keempat materi yang diajarkan tidak sebatas kitab kuning saja. Dengan demikian judul diatas bermaksud untuk meneliti mengenai hal hal yang baru dalam proses pembelajaran pada pondok pesantren khususnya pesantren entrepreuner.

\subsection{Pengertian Entrepreunership}

Entrepreunership atau kewirausahaan, berasal dari entrepreuner (wirausahawan) yang menurut kuratko dan hodgetts sebagaimana dikutip oleh manurung dalam bukunya Muh Yunus, mengatakan bahwa entrepreuner (wirausahawan), berasal dari bahasa perancis entreprende yang berarti mengambil pekerjaan (to undertake). Konsep mengenai 
entrepreuner adalah: the entrepreuner is one who undertakes to arganize, manage, and assume the risk of bussines. (Yunus, 2008).

Kata wirausaha berkaitan dengan kegiatan usaha atau kegiatan bisnis pada umumnya. Wirausahawan adalah seseorang yang memiliki kemampuan menilai peluang-peluang usaha (bisnis) dan mengkombinasikan berbagai macam sumber daya (resources) yang dibutuhkan untuk mengambil tindakan yang tepat untuk meraih keuntungan dimasa depan. Wirausaha pada hakekatnya adalah sifat, ciri dan watak seseorang yang memiliki kemampuan dalam mewujudkan gagasan inovatif kedalam dunia nyata. (Yunus, 2008).

Intinya seorang wirausahawan adalah orang orang yang memiliki jiwa wirausaha dan mengaplikasikan hakekat kewirausahaan dalam hidupnya. Orang-orang yang memiliki kreatifitas yang tinggi dalam hidupnya. Terdapat ciri umum yang selalu ada dalam diri wirausahawan, yaitu kemampuan mengubah sesuatu menjadi lebih baik atau menciptakan sesuatu yang benar-benar baru, atau berjiwa kreatif dan inovatif ini sebagai sifat yang terdapat pada diri wirausahawan (Suharyadi, 2007).

\subsection{Pengertian Pendidikan Entrepreneur}

Pendidikan entrepreneur terdiri dari kata pendidikan dan entrepreunership. Pendidikan merupakan kata benda yang dibentuk berdasarkan kata asal didik yang berarti memelihara dan member latihan (ajaran, tuntutan, pimpinan) mengenai akhlak dan kecerdasan pikiran. Dengan demikian pendidikan merupakan proses pengubahan sikap dan tata laku seseorang atau kelompok dalam usaha mendewasakan manusia melalui upaya pengajaran dan pelatihan. (Porwadarminta, 1976).

Sedangkan entrepreuner berarti kewirausahaan, kewiraswastaan (Echols, 2000) Secara etimologis, sebenarnya kewirausahaan hakikatnya adalah suatu kemampuan dalam berfikir kreatif dan berperilaku inovatif yang menjadi dasar, sumber daya, tenaga penggerak, tujuan, siasat dan kiat dalam menghadapi tantangan hidup. (Yunus, 2008).

Dalam beberapa pengertian tersebut, pendidikan entrepreuner dapat diartikan sebagai suatu bentuk upaya pengubahan tingkah laku seseorang untuk dapat berfikir kreatif inovatif dalam memecahkan persoalan dan menemukan peluang untuk memperbaiki kehidupan.

\subsection{Pengertian Pesantren Entrepreuner}

Meninjau dari pengertian pesantren, entrepreuner dan pendidikan entrepreuner, dalam hal ini pesantren entrepreuner memiliki makna lembaga pendidikan islam yang mempunyai visi dan misi membentuk 
santrinya menjadi wirausaha yang mempunyai moral dan akhlaq yang baik. Pesantren entrepreuner adalah pesantren yang memiliki kegiatan dakwah dan wirausaha. Meningkatkan jiwa entrepreunership pada anak didiknya.

\subsection{Konsep Pemberdayaan Masyarakat}

\subsubsection{Pemberdayaan Masyarakat}

Asal kata 'pemberdayaan' dalam kamus umum bahasa Indonesia (WJS Poerwadarminta, 1985) adalah 'daya'. Arti daya adalah kekuatan atau tenaga, misalnya: daya piker, daya batin, daya gaib, daya gerak, daya usaha, daya hidup, daya tahan, sudah tak ada dayanya lagi. Daya juga berarti pengaruh, misalnya: memang tak sedikit daya pendidikan barat kepada para pujangga angkatan baru. Arti lain dari kata 'daya' adalah akal, jalan (cara, ikhtiar), misalnya: apa daya, seribu daya, bermacammacam daya, habis segala daya untuk mengatasi kesulitan itu. (Bahri, 2013).

Dalam kamus bahasa Indonesia ini, disebutkan daya juga berarti muslihat, misalnya tipu daya. Kata mendaya(kan) atau memperdaya(kan) artinya mengakali, menipu, mengenakan tipu muslihat, misalnya: didaya iblis, orang yang bodoh mudah diperdayakan. Mendayai artinya mengakali, menipu, mempengaruhi. Terperdaya artinya tertipu, sedangkan tidak terperdaya artinya tidak ditipu. Pendayaan artinya penipuan, sedangkan perdayaan artinya tipu daya, tipu muslihat. Tetapi disebutkan pula dalam kamus ini, kata mendayai juga berarti member daya, member kekuatan, memberi tenaga. Selanjutnya disebutkan kata berdaya artinya berkekuatan, bertenaga dan akal. Tidak berdaya artinya tidak ada tenaga lagi, atau hilang akal, purus harapan. Berdaya upaya artinya berusaha untuk berikhtiar dengan sungguh-sungguh, misalnya: kita wajib berdaya upaya untuk memperbaiki kehidupan kita. (Bahri, 2013).

Pemberdayaan berasal dari penerjemahan bahasa inggris "empowernment" yang juga dapat bermakna "pemberian kekuasaan". Karena power bukan sekadar "daya", tetapi juga "kekuasaan", sehingga kata "daya" tidak saja bemakna "mampu", tetapi juga mempunyai kuasa. (Bahri, 2013)

Sebenarnya hakekat redefinisi pemberdayaan adalah: pertama, pemberdayaan adalah proses, yaitu perubahan dari status yang rendah ke status yang lebih tinggi. Kedua, pemberdayaan adalah metode, yaitu sebagai suatu pendekatan agar masyarakat berani mengungkapkan pendapatnya. Ketiga, pemberdayaan adalah program, yaitu sebagai 
tahapan-tahapan yang hasilnya terukur menuju kehidupan rakyat yang mandiri dan sejahtera. Keempat, pemberdayaan adalah gerakan, yaitu membuka peluang bagi masyarakat untuk berpartisipasi dalam pembangunan. Kelima, pemberdayaan adalah pemberian otorisasi, yaiutu menempatkan masyarakat sebagai subyek dalam pembangunan. Jadi pemberdayaan harus dilihat secara komprehensif dengan produk akhir masyarakat menjadi berdaya, memiliki otoritas, menjadi subyek dalam pembangunan, dan kehidupannya menjadi lebih baik dari sebelumnya. (Bahri, 2013).

Pemberdayaan berarti menyiapkan kepada masyarakat sumberdaya kesempatan atau peluang, pengetahuan dan keahlian untuk meningkatkan kapasitas diri masyarakat didalam menentukan masa depan mereka, serta berpartisipasi dan mempengaruhi kehidupan dalam komunitas masyarakat itu sendiri. (Bahri, 2013).

Menurut Jim Ife, pemberdayaan adalah memberikan sumberdaya, kesempatan, pengetahuan, dan keterampilan kepada warga untuk meningkatkan kemampuan mereka dalam menentukan masa depannya sendiri dan berpartisispasi dalam dan mempengaruhi kehidupan dari masyarakatnya (empowerment means providing people with the resources, opportunities, knowledge and skills to increase their capacity to determine their own future, and to participate in and affect the life of their community). (Zubaedi, 2013).

Sementara itu, world bank mengartikan pemberdayaan sebagai perluasan asset dan kemampuan masyarakat miskin dalam menegosiasikan dengan, mempengaruhi, mengontrol, dan mengendalikan tanggungjawab lembaga-lembaga yang mempengaruhi kehidupannya. (Empowerment is expansion of assets and capabilities of poor people to participate in, negotiate with, influence, control and hold accountable institutions that affect their live). (Zubaedi, 2013).

Konsep pemberdayaan masyarakat jika ditelaah sebenarnya berangkat dari pandangan yang menempatkan manusia sebagai subyek dari dunianya sendiri. Pola dasar gerakan pemberdayaan ini mengamanatkan kepada perlunya power dan menekankan keberpihakan kepada kelompok yang tak berdaya.

\subsection{Pengembangan Masyarakat}

Pengembangan masyarakat adalah upaya mengembangkan sebuah kondisi masyarakat secara berkelanjutan dan aktif berdasarkan prinsipprinsip keadilan social dan saling menghargai. Para pekerja kemasyarakatan berupaya menfasilitasi warga dalam proses terciptanya 
keadilan social dan saling menghargai melalui program-program pembangunan secara luas yang menghubungkan seluruh komponen masyarakat. Pengembangan masyarakat menerjemahkan nilai-nilai keterbukaan, persamaan, pertanggungjawaban, kesempatan, pilihan, partisipasi, saling menguntungkan, saling timbal balik, dan pembelajaran terus menerus. Inti dari pengembangan masyarakat adalah mendidik, membuat anggota masyarakat mampu mengerjakan sesuatu dengan memberikan kekuatan atau sarana yang diperlukan dan memberdayakan mereka. (Zubaedi, 2013).

Pengembangan masyarakat menurut PBB (1956) adalah: "community development is the process by which the effort of the people themselves are united with thoses of governmental authorities to improve the economic, social and cultural conditions of communities to integrate these communities into the life of the nation and to enable them to contribute fully to national progress this complex of process in this made up of two essensialelements the participation of the people themselves of their own initiative which encourageinitiative, self-helf and mutual help and make these effective".

"proses dimana warga masyarakat bersatu dengan pejabat pemerintah untuk memperbaiki kondisi ekonomi, social dan budaya masyarakat untuk mengintegrasikan kehidupan masyarakat kedalam kehidupan bangsa guna memungkinkan memberikan sumbangan penuh terhadap kemajuan bangsanya". (Bahri, 2013).

Lee J. Carry (1970) dalam Effendi (2008:13) lebih lanjut mendefinisikan pengembangan masyarakat sebagai: "The deliberate attempt by people to work together to guide the future of communities and the development of a corresponding set of techniques for assisting communities people in such process". (Pengembangan masyarakat merupakan upaya mengorganisir dari orang dalam masyarakat local terhadap berbagai kondisi yang mempengaruhi secara negative atau mengancam kehidupan mereka). (Bahri, 2013).

Pengembangan masyarakat adalah komitmen dalam memberdayakan masyarakat lapis bawah sehingga mereka memiliki berbagai pilihan nyatamenyangkut masa depannya. Masyarakat lapis bawah umumnya terdiri atas orang-orang lemah, tidak berdaya dan miskin karena tidak memiliki sumber daya atau tidak memiliki kemampuan untuk mengontrol saran produksi. Mereka umumnya terdiri atas buruh, petani penggarap, petani berlahan kecil, para nelayan, masyarakat hutan, kalangan pengangguran, orang cacat dan orang-orang 
yang dibuat marginal karena umur, keadaan gender, ras, dan etnis. (Zubaedi, 2013)

\subsection{Kesejahteraan Sosial}

Merujuk pada spicker (1995), midgley, Tracy dan Livermore (2000), Thompson (2005), Suharto (2005a), dan Suharto (2006b), dalam Efri S. Bahri (2013:63) pengertian kesejahteraan sedikitnya mengandung empat makna, yaitu:

1. Sebagai kondisi sejahtera (well-being). Pengertian ini biasanya menunjuk pada istilah kesejahteraan social (social welfare) sebagai kondisi terpenuhinya kebutuhan material dan non material. Midgley, et al (2000:xi) mendefinisikan kesejahteraan social sebagai “.... a condition or state of human well-being." Kondisi sejahtera terjadi manakala kehidupan manusia aman dan bahagia karena kebutuhan dasar akan gizi, kesehatan, pendidikan, tempat tinggal, dan pendapatan dapat dipenuhi; serta manakala manusia memperoleh perlindungan dari resiko-resiko utama yang mengancam kehidupannya.

2. Sebagai pelayanan social. diInggris, Australia dan Selandia Baru, pelayanan social umumnya mencakup lima bentuk, yakni jaminan social (social security), Bush dan Blair kini mengambil jalan baru yang dikenal dengan istilah the Third Way, jalan ketiga, yang dipromosikan oleh Antony Giddens, (Edi Suharto, WelfareState Depsos/2006), pelayanan kesehatan, pendidikan, perumahan dan pelayanan sisial personal (personal social services).

3. Sebagai tunjangan social, khususnya di amerika Serikat (AS), diberikan kepada orang miskin. Karena sebagian besar penerima welfare adalah orang-orang miskin, cacat, pengangguran, keadaan ini kemudian menimbulkan konotasi negative pada istilah kesejahteraan, seperti kemisikinan, kemalasan, ketergantungan, yang sebenarnya lebih tepat disebut "social illfare" ketimbang "social welfare".

4. Sebagai proses atau usaha terencana yang dilakukan oleh perorangan, lembaga-lembaga social, masyarakat maupun badan-badan pemerintah untuk meningkatkan kualitas kehidupan (pengertian pertama) melalui pemberian pelayanan social (pengertian kedua) dan tunjangan social (pengertian ketiga).

Di Indonesia, konsep kesejahteraan merujuk pada konsep pembangunan kesejahteraan sosial, yakni serangkaian aktivis yang terencana dan melembaga yang ditujukan untuk meningkatkan standard an kualitas kehidupan manusia. Sebagai sebuah proses untuk 
meningkatkan kondisi sejahtera, istilah 'kesejahteraan' sejatinya tidak perlu pakai kata 'sosial' lagi, karena sudah jelas menunjuk pada sector atau bidang yang termasuk dalam wilayah pembangunan social. Sector 'pendidikan' dan 'kesehatan' juga termasuk dalam wilayah pembangunan social dan tidak memakai embel-embel 'sosial' atau 'manusia'.

James Migley mencoba mendefinisikan kesejahteraan social sebagai suatu kondisi dalam suatu masyarakat. Midgley (1997:5) melihat kesejahteraan social sebagai: "a state or condition of human well-being that exists when social problems are managed, when human are met, and when social opportunities are maximized" (suatu keadaan atau kondisi kehidupan manusia yang tercipta ketika berbagai permasalahan social dapat dikelola dengan baik: ketika kebutuhan manusia dapat terpenuhi dan ketika kesempatan social dapat dimaksimalkan). (Adi, 2013).

Sedangkan diIndonesia, pengertian kesejahteraan social tidak dapat dilepas dari apa yang telah dirumuskan dalam undang-undang Nomor 11 tahun 2009 tentang kesejahteraan social, pasal 1 ayat 1: "kesejahteraan social ialah kondisi terpenuhinya kebutuhan material, spiritual, dan social warga Negara agar dapat hidup layak dan mampu mengembangkan diri, sehingga dapat melaksanakan fungsi sosialnya."

Menurut Isbandi Rukminto (2013:23) kesejahteraan social adalah suatu tatanan (tata kehidupan) yang meliputi kehidupan material maupun spiritual, dengan tidak menempatkan satu aspek lebih penting dari yang lainnya, tetapi lebih mencoba melihat pada upaya mendapatkan titik keseimbangan. Titik keseimbangan yang dimaksud adalah keseimbangan antara aspek social, material, dan spiritual.

\subsection{Lembaga Swadaya Masyarakat (LSM)}

Istilah lembaga berasal dari kata"institution" yang menunjukkan sesuatu yang sudah mapan (established). Lembaga ini mulanya terbentuk dari suatu kebiasaan yang dilakukan secara terus menerus sampai menjadi adat istiadat, kemudian bekembang menjadi tata kelakuan. Soerjono soekanto (2003) menyimpulkan dari sudut pandang sosiologis dengan meletakkan institusi sebagai lembaga kemasyarakatan, yaitu sebagai suatu jaringan dai proses-proses hubungan antar manusia dan antar kelompok yang berfungsi memelihara hubungan-hubungan tersebut serta polapolanya, sesuai dengan kepentingan-kepentingannya. (Bahri, 2013).

Lembaga Swadaya Masyarakat (LSM) termasuk salah satu bagian dari organisasi civiel society yang menaruh perhatian pada urusan-urusan kemasyarakatan yang umumnya dikelola dalam wadah kelompok social serta memobilisasi sumberdaya berdasarkan nilai-nilai dan visi social. 
Di Indonesia istilah SLM telah didefinisikan secara tegas dalam instruksi mentri dalam negri (Inmendagri) No.8/1990 yang disebarluaskan kepada gubernur seluruh Indonesia yang secara sukarela atau kehendak sendiri berniat serta bergerak dibidang kegiatan tertentu yang ditetapkan oleh organisasi/lembaga sebagai wujud partisipasi masyarakat dalam upaya meningkatkan taraf hidupdan kesejahteraan masyarakat, yang menitikberatkan kepada pengabdian secara swadaya (Zubaedi, 2013).

\section{PEMBAHASAN}

\subsection{Model pemberdayaan masyarakat di pesantren entrepreuner}

Konsep pemberdayaan dalam wacana pembangunan masyarakat selalu dihubungkan dengan konsep mandiri, partisipasi, jaringan kerja, dan keadilan. Pada dasarnya, pemberdayaan diletakkan pada kekuatan tingkat individu dan social.

Menurut McArdle (1989) mengartikan pemberdayaan sebagai proses pengambilan keputusan oleh orang-orang yang secara konsekuen melaksanakan keputusan tersebut. Orang-orang yang telah mencapai tujuan kolektif diberdayakan melalui kemandiriannya, bahkan merupakan "keharusan" untuk lebih diberdayakan melalui usaha mereka sendiri dan akumulasi pengetahuan, keterampilan serta sumber lainnya dalam rangka mencapai tujuan mereka tanpa bergantung pada pertolongan dari hubungan eksternal. (Adimihadja, 2004).

Partisipasi merupakan komponen penting dalam pembangkitan kemandirian dan proses pemberdayaan. (Adimihadja, 2004) Sebaiknya, orang-orang harus terlibat dalam proses tersebut sehingga mereka dapat lebih memperhatikan hidupnya untuk memperoleh rasa percaya diri, memiliki harga diri dan pengetahuan untuk mengembangkan keahlian baru. Prosesnya dilakukan secara kumulatif sehingga semakin banyak keterampilan yang dimiliki seseorang, semakin baik kemampuan berpartisipasinya.

Dalam hal ini cara terbaik untuk bisa mengatasi masalah pembangunan adalah membiarkan semangat wiraswasta tumbuh dalam kehidupan masyarakat, berani mengambil resiko, berani bersaing, menumbuhkan semangat untuk bersaing, dan menemukan hal-hal baru (inovasi) melalui partisipsi masyarakat.

Penulis mencoba memaparkan model apa saja yang dipakai pesantren entrepreuner dalam pemberdayaan masyarakat menurut hasil wawancara kepada bendahara pesantren entrepreuner.

a. Model yang dipakai pesantren entrepreuner dalam pemberdayaan masyarakat yang pertama adalah membuat koperasi berbasis 
syari'ah yang mereka namakan dengan KOSPE (Koperasi syari'ah Pesantren Entrepreuner).

Dengan visi menjadi lembaga keuangan syari'ah yang mampu meningkatkan usaha kecil menengah agara dapat bersaing di pasar internasional. Dan dengan misi bekerjasama menumbuh kembangkan usaha kecil menengah dengan memfasilitasi kegiatan usaha tersebut bersama jaringan dan membentuk pasar halal yang menjangkau masyarakat nasional dan internasional.

Koperasi Syari'ah Pesantren Entrepreneur memiliki pelayanan berupa Pinjaman Produktif dalam program 5 Juta 1 lapangan pekerjaan serta menyediakan layanan Konsumtif bagi para anggotanya. Koperasi syariah juga memiliki beberapa pelayanan, diantaranya:

a. Simpanan haji dan umroh.

b. Simpanan pernikahan

c. Simpanan pendidikan

d. Simpanan qurban

e. Investasi

f. Koperasi syariah juga bekerjasama dengan penyedia pembayaran listrik, telepon, air, dan lain sebagainya.

b. Smart Learning Centre (SLC), merupakan model yang dikhususkan pada bidang pendidikan yang bergerak dalam upaya mengeksplorasi seluruh potensi kaum muda dan remaja, dengan memberikan pemahaman akan arti penting kehidupan. Sehingga akan terbentuk individu-individu yang mampu menghasilkan presatsi gemilang sesuai dengan potensi yang dimiliki, serta mampu menghasilkan kehidupan yang menawan dan masa depan yang cerah.

SLC memiliki beberapa program yang berkelanjutan diantaranya:

a. Pelatihan motivasi untuk siswa-siswi SMP dan SMA (melejitkan potensi belajar siswa)

b. Meningkatkan nilai UAN SMP dan SMA

c. Membuat komunitas pelajar hebat (pelajar yang berprestasi)

d. Training pengembangan karakter di pondok pesantren

c. Pesantren Entrepreuner Pondok Sedekah (PSPE), Pondok Sedekah Pesantren Entrepreneur adalah lembaga yang bergerak di bidang sosial terutama dibidang penghimpunan dana Zakat, Infak dan sedekah serta wakaf. Dana dana yang diamanahkan melalui Pondok Sedekah Pesantren Entrepreneur Insya Allah akan disalurkan melalui berbagai program diantaranya program 
ekonomi, Pendidikan, kesehatan serta kegawat daruratan atau bencana. PSPE memiliki program yang berjalan sampai sekarang, diantaranya:

a. Memiliki donator tetap

b. Kencleng disetiap rumah

c. Pelatihan kewirausahaan, pelatihan al-hijamah (bekam) untuk marbot masjid

d. Menyalurkan dana infak, shodaqoh dan paket lebaran untuk yatim dan dhu'afa

e. Ifthor on the road

d. Selanjutnya adalah Rumah Quran Pesantren Entrepreuner, Rumah Quran Pesantren Entrepreuner bergerak mengenalkan Al-Quran kepada masyarakat luas agar seimbang antara dunia dan akhirat.

Rumah Quran Pesantren Entrepreuner sudah berjalan 4 tahun, selama 4 tahun program ini berjalan, RQPE memiliki banyak program yang masih berjalan hingga sekarang, diantaranya:

a. Studi Quran Intensif (SQI). Bekerjasama dengan manajemen kampus Bani Saleh. Dan program ini menjadi program wajib kampus dalam nilai mata kuliah agama. Program ini berbentuk halaqoh quran diluar jam kuliah dengan sifat wajib. Satu kelompok terdiri dari sepuluh mahasiswa dan satu ustadz.

b. Menuju hafidz Indonesia. Anak usia 3 tahun sampai dengan SMP yang tidak bisa membaca al-quran mampu menghafal juz 'amma dengan metode talqin, mereka dituntun menghafal setiap ayat.

Hasil yang sudah diperoleh adalah memberantas buta huruf alquran. Mahasiswa yang tidak bisa sama sekali dalam waktu satu semester mampu membaca al-quran.

e. Dan yang terakhir adalah Rumah kreatif, yaitu memberdayaan pemuda dengan mengajarkan kepada mereka design dengan menggunakan photosop dan corel draw. Program ini sudah berjalan selama 4 tahun. Hasil dari program ini adalah:

a. Membuat buletin jum'at setiap pekan

b. Membuat album kenangan untuk sekolahan

c. Membuat kalender tiap tahunnya 


\subsection{Peran Pesantren Entrepreuner Dalam Pemberdayaan Masyarakat}

Berbicara mengenai LSM (Lembaga Swadaya Masyarakat) dalam benak masyarakat tak lepas dari peran apa saja yang diberikan lembaga tersebut dalam pemberdayaan msyarakat.

Pesantren Entrepreuner memiliki tiga peran dalam pemberdayaan masyarakat, yaitu:

1. Ekonomi. Dalam bidang ekonomi pesantren entrepreuner membentuk suatu badan koperasi syariah yang disebut KOSPE (Koperasi Syariah Pesantren Entrepreuner). KOSPE telah membina 100 unit usaha kecil mandiri dari kabupaten dan kota bekasi dan beberapa UKM dijakarta. Dan mengadakan pertemuan kepada para pengusaha satu bulan sekali di radio dakta atau masjid almuhajirin.

2. Sosial. Dalam bidang sosial Pesantren Entrepreuner mendirikan suatu badan organisasi PSPE (Pondok Sedekah Pesantren Entrepreuner). Bergerak dalam bidang lembaga amil zakat serta wakaf. Memberikan bantuan kepada beberapa anggota majlis talim yang terlibat riba atau rentenir.

3. Pendidikan. Program pendidikan mempunyai dua unit organisasi, yaitu: PEBS (Pesantren Entrepreuner Business School). Yaitu dengan memberikan pelatihan ke perusahaan, memberikan training-training kepada pelajar tingkat SMA atau SMK kota dan kabupaten bekasi untuk menjadi siswa-siswa yang exelent. Khusus untuk SMA dan SMK, PEBS lebih memfokuskan pada Pembentukan karakter. PEBS telah bekerjasama dengan beberapa perusahaan diantaranya Perusahaan Bridgestone, Perusahaan Astra, PERTAMINA, dan MENDAGRI. Rumah Quran Pesantren Entrepreuner, yaitu program yang mengajarkan kepada masyarakat mengenai al-quran baik dari cara membaca al-quran dan menghafal al-quran.

\section{KESIMPULAN}

Berdasarkan hasil penelitian yang telah diuraikan oleh penulis, maka kesimpulan yang diperoleh adalah sebagai berikut: Bahwa peran Pesantren Entrepreneur sebagai lembaga yang memili banyak program pemberdayaan masyarakat mampu memberikan banyak dampak positif kepada masyarakat. Diantara program pemberdayaan yang memiliki dampak positif terhadap masyarakat adalah: 
- Ekonomi, yaitu memiliki pelayanan berupa Pinjaman Produktif dalam program 5 Juta 1 lapangan pekerjaan serta menyediakan layanan Konsumtif bagi para anggotanya.

- Pendidikan terdiri dari dua program yaitu: 1) Memberikan trainingtraining keperusahaan dan training tentang pendidikan karakter kepelajar-pelajar SMA sederajat. 2) Mengajarkan kemasyarakat cara baca Al-Quran dan memberikan motivasi kepada masyarakat agar mereka mau menghafal Al-Quran serta mendampingin mereka yang ingin menghafal Al-Quran.

- Sosial, yaitu dengan membuat lembaga amil zakat, wakaf, dan shodaqoh.

\section{DAFTAR PUSTAKA}

Adi, R. I. (2013). Kesejahteraan Sosial. Jakarta: Rajawali Press.

Adimihadja, K. (2004). Strategi Pemberdayaan Masyarakat. Bandung: Humaniora Utama Press.

Amin, M. (2010). Kyai Entrepreuneur. Jakarta: Panitia Tasyakuran.

Bahri, S. Bahri. (2013). Pemberdayaan Masyarakat Konsep Dan Aplikasi. Kediri: FAM Publishing.

Echols, J. M. (2000). Kamus Bahasa Inggris Indonesia. Jakarta: PT Gramedia.

Ma'arif, S. (2008). Pesantren Vs Kapitalisme Sekolah. Jakarta: Needs Press.

Mastuhu. (1994). Dinamika Sistem Pendidikan Pesantren. Jakarta: INIS.

Porwadarminta, W. (1976). Kamus Umum Bahasa Indonesia. Jakarta: Balai Pustaka.

Rukmana, R. (2013). Peran BMT Dalam Pemberdayaan Masyarakat. Jakarta: SEBI.

Suharyadi. (2007). Kewirausahaan, Menmbangun Usaha Sukses Sejak Usia Muda. Jakarta: Salemba Empat.

Yunus, M. (2008). Islam Dan kewirausahaan. Malang: UIN Malang Press.

Zarkasyi, I. (1996). Pekan Perkenalan. Ponorogo: Gontor Press.

Zubaedi. (2013). Pengembangan Masyarakat wacana Dan Praktik. Jakarta: Kencana Prenada Media Group. 